\title{
COMMENTS ON “AMERICA'S OLDEST BASKETRY”
}

\author{
Thomas J Connolly \\ State Museum of Anthropology, University of Oregon, Eugene, Oregon 97403 USA \\ William J Cannon \\ Bureau of Land Management, Lakeview District, PO Box 151, Lakeview, Oregon 97630 USA
}

\begin{abstract}
A recent publication on directly dated basketry specimens from the western United States (Berger et al. 1998, Radiocarbon 40(2):615-20) contained some misleading information, and in a few cases discussed radiocarbon ages from unacknowledged sources. We provide the missing original citations along with some clarifications. We focus especially on the age of distinctive Fort Rock and Multiple Warp-style sandals, for which we provide additional previously unreported ${ }^{14} \mathrm{C}$ ages. Direct dates on fibers from Fort Rock sandals from 3 different sites range in age from 10,500 cal BP to about $9200 \mathrm{cal}$ BP. Contextual evidence suggests that Multiple Warp sandals may date as early as 6600 cal BP, but the few directly dated specimens are less than $1000 \mathrm{yr}$ old.
\end{abstract}

\section{INTRODUCTION}

In “America's Oldest Basketry," a short contribution by Berger et al. (Radiocarbon 40(2):615-20 [1998]), calibrated ranges are presented for previously reported radiocarbon ages on archaeological basketry specimens from western North America. The article contains a number of factual errors. Further, some dates, but not all, are cited as reports from ${ }^{14} \mathrm{C}$ labs by the senior author and others (Berger et al. 1965; Berger and Libby 1966), but some primary sources are not acknowledged. In no case are published reports by the sample submitter credited, although these would lead the reader to important contextual information and technical descriptions of the specimens.

The ${ }^{14} \mathrm{C}$ ages discussed by Berger et al. (1998) were all reported in works published between 1951 and 1982 (Table 1), and calibrated ranges for some of the dates have been previously reported (e.g. Connolly et al. 1995). We offer here a brief comment on the material mentioned from the central and southern Great Basin, then discuss the twined sandals from the south-central Oregon caves in greater detail.

\section{DESCRIPTIVE BACKGROUND}

In the caption to their Figure 1, Berger et al. identify an age of 2440 BP as the "earliest date for coiled technique". This may be the case for the Falcon Hill, Nevada, sites where this dated specimen was recovered (Hattori 1982), but it is not true for the general region (Figure 1). Coiled basketry was recovered from strata considerably older than $5000 \mathrm{yr}$ at Hogup Cave, Danger Cave, and other sites in the eastern Great Basin (Adovasio 1970, 1986; Aikens 1970). While it is possible that this and other statements were intended to specifically reference the Falcon Hill basketry assemblage, with which the authors were familiar, this is not made clear in the text, and is not the case implied by the paper's title. In another case, the Berger et al. Figure 3 caption identifies plain twined, s-twist basketry, dated to $3900 \mathrm{BP}$, as the "last known occurrence" of this type. Again, this may be true for directly dated specimens from the Falcon Hill sites, but examples of this type are common in late prehistoric and ethnographic collections from the Great Basin (e.g., Adovasio 1986; Connolly et al. 1998; Fowler and Dawson 1986).

Berger et al.'s Figure 7 identifies the pictured artifacts as "Fort Rock, Oregon" sandals; the upper photo is a Fort Rock-style sandal, as defined by Cressman (1942, p 57-8). While the pictured specimen may indeed have come from Fort Rock Cave, specific source information, such as accession or specimen number, is not provided. Sandals of this type have been found in a number of northern 


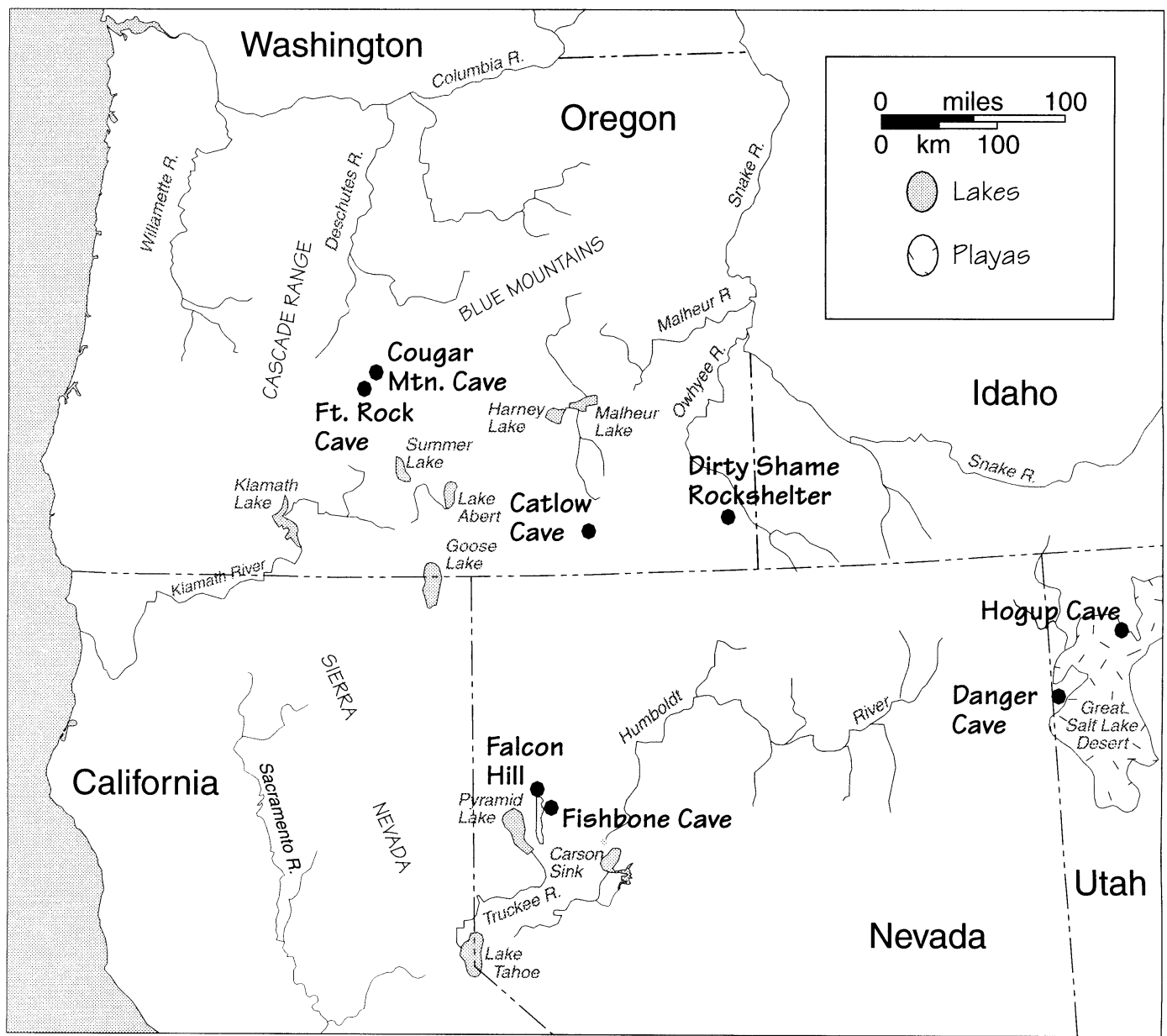

Figure 1 Locations of basketry-producing archaeological sites mentioned

Great Basin sites (Andrews et al. 1986; Connolly 1994; Cowles 1959; Cressman 1942). Berger et al. (1998, p 620) identify an unacknowledged date of $8410 \pm 250$ BP from a Fort Rock-style sandal from Cougar Mountain Cave; this was originally reported by Fergusson and Libby (1962) as $8510 \pm$ 250 BP (Table 1).

The lower photo in Berger et al.'s Figure 7 shows sandals that are neither the Fort Rock type, nor from Fort Rock Cave; this pair of child-sized sandals was recovered from the upper levels of Catlow Cave by a crew under the supervision of Luther Cressman in 1937, and reported and illustrated in his 1942 publication. These sandals fit into the "Multiple Warp" type described by Cressman (1942, p 58). One sandal from this pair (Berger et al. 1998, Figure 7b; University of Oregon Museum of Natural History Accession 56, specimen 1-3112) has only recently been dated to $950 \pm 45 \mathrm{BP}$ (Table 1), effectively identical to the $959 \pm 150 \mathrm{BP}$ age reported by Cressman $(1951, \mathrm{p} 308)$ on a fire-hardened digging stick also collected from the upper levels of the site, and believed by him to be "from near the end of occupation" of the cave. 
Table 1 Directly dated Fort Rock and Multiple Warp style sandals, northern Great Basin

\begin{tabular}{|c|c|c|c|c|c|}
\hline Lab no. & $\begin{array}{l}{ }^{14} \mathrm{C} \text { age } \\
(\mathrm{yr} \mathrm{BP})\end{array}$ & $\begin{array}{l}\text { Age range } \\
(\text { cal BP, } 1 \sigma)\end{array}$ & Material & Site & $\begin{array}{l}\text { Reference(s), } \\
\text { comments }\end{array}$ \\
\hline \multicolumn{6}{|c|}{ Fort Rock-Style Sandals } \\
\hline C-428a & $9188 \pm 480^{\mathrm{a}}$ & $10,920-9650$ & Sagebrush bark & Fort Rock Cave & $\begin{array}{l}\text { Arnold and Libby } \\
1951\end{array}$ \\
\hline$C-428 b$ & $8916 \pm 540^{\mathrm{a}}$ & $10,440-9380$ & Sagebrush bark & Fort Rock Cave & $\begin{array}{l}\text { Cressman 1951; } \\
\text { Bedwell and Cress- } \\
\text { man } 1971\end{array}$ \\
\hline AA $-30056^{\mathrm{b}}$ & $8308 \pm 43$ & 9380-9240 & Sagebrush bark & Catlow Cave & $\begin{array}{l}\text { Not previously } \\
\text { reported }\end{array}$ \\
\hline UCLA-112 & $8510 \pm 250$ & 9840-9240 & Tule & $\begin{array}{l}\text { Cougar Mtn. } \\
\text { Cave }\end{array}$ & $\begin{array}{l}\text { Fergusson and } \\
\text { Libby } 1962 ; \text { Con- } \\
\text { nolly } 1994\end{array}$ \\
\hline I- 1917 & $8500 \pm 140$ & 9530-9380 & Sagebrush bark & Fort Rock Cave & $\begin{array}{l}\text { Bedwell and Cress- } \\
\text { man } 1971\end{array}$ \\
\hline AA-9249 & $9215 \pm 140$ & $10,360-10,020$ & Sagebrush bark & Fort Rock Cave? ${ }^{\mathrm{c}}$ & $\begin{array}{l}\text { Not previously } \\
\text { reported }\end{array}$ \\
\hline AA-9250 & $8715 \pm 105$ & $9870-9520$ & Sagebrush bark & Fort Rock Cave? ${ }^{\mathrm{c}}$ & $\begin{array}{l}\text { Not previously } \\
\text { reported }\end{array}$ \\
\hline \multicolumn{6}{|c|}{ Multiple Warp Sandals } \\
\hline WSU-4198 & $820 \pm 60$ & $780-670$ & Tule & S. Warner Cave & $\begin{array}{l}\text { Fowler and Cannon } \\
\text { 1992; Eiselt } 1997\end{array}$ \\
\hline AA-30055 & $950 \pm 45$ & $930-790$ & Sagebrush bark ${ }^{\mathrm{d}}$ & Catlow Cave & $\begin{array}{l}\text { Not previously re- } \\
\text { ported }\end{array}$ \\
\hline
\end{tabular}

aThe commonly cited $9053 \pm 350$ age for the "Fort Rock sandal" is actually an average of these 2 dates, run on "several pairs of woven rope sandals" (Arnold and Libby 1951, p 117). The weighted average of these 2 ages produces an age range of $10,390-9650$ cal BP.

${ }^{\mathrm{b}}$ Specimen 1-3583, Accession 56, State Museum of Anthropology, Eugene, Oregon.

'Reportedly recovered from Fort Rock Cave ca. 1928 by local residents, subsequently donated to the Lake County Museum, Lakeview, Oregon.

${ }^{\mathrm{d}}$ Child-sized sandal, specimen 1-3112, accession 56, Oregon State Museum of Anthropology; pictured by Berger et al. (1998), Figure 7.

\section{DISCUSSION}

\section{Fort Rock Sandals}

Named for the site where several dozen examples were recovered from a cache buried beneath the approximately 7500-yr-old Mazama volcanic ash, Fort Rock-style sandals are described as having a flat close-twined sole, usually with 5 rope warps (although variation has been noted; Connolly 1994, p 73). Twining proceeded from the heel to the toe, where the warps are subdivided into finer warps and turned back to form an open-twined toe flap (refer to Berger et al. 1998, Figure 7a). A tie rope attached to one edge of the sole presumably wrapped around the ankle and fastened to the opposite edge (Cressman 1942, p 57).

Andrews et al. (1986) suggest that Fort Rock-style sandals may occur in Dirty Shame Rockshelter as late as about $6000 \mathrm{yr}$ ago, based on stratigraphic associations. Table 1 summarizes all known ${ }^{14} \mathrm{C}$ ages from directly dated Fort Rock sandals. Most dated specimens are from Fort Rock Cave, but directly dated sandals of this type are also known from Cougar Mountain and Catlow Caves. Directly dated Fort Rock style sandals range in age from at least 10,500 cal BP to about 9200 cal BP. 


\section{Multiple Warp Sandals}

Multiple Warp-style sandals are open or close twined from heel to toe, but have from 8 to more than a dozen warps "arranged in a series of parabolas around the heel" to form a pocket (Cressman 1942, p 58). Loose warps are bent back to form a toe cover, but are rarely twined. Loops built into the sole were pulled together across the top of the foot and secured with a tie (see also Berger et al. 1998, Figure 7b).

Adovasio (1986, p 197) has reported that a sandal similar to the northern Great Basin Multiple Warp type was recovered from Fishbone Cave in western Nevada in strata predating about 8200 cal BP. Andrews et al. (1986) report that Multiple Warp sandals were recovered from Zone VI in Dirty Shame Rockshelter in southeast Oregon, which predates about 6600 cal BP. While these associations appear to be valid, cave deposits can be quite disturbed, and Multiple Warp sandals from the northern Great Basin that have been directly dated-or are clearly associated with ${ }^{14} \mathrm{C}$-dated features (Table 1; also see Eiselt 1997; Marchesini 1994)_are consistently much younger. Andrews et al. (1986, p 126) suggest that Multiple Warp sandals first appear in the northern Great Basin after 8000 cal BP, and were made up to the time of Euroamerican contact.

\section{CONCLUSION}

The distinctive Fort Rock and Multiple Warp sandal types appear to be of dramatically different ages. All directly dated Fort Rock style sandals predate $9000 \mathrm{cal}$ BP, although it is possible sandals of this type were made until $7000 \mathrm{cal}$ BP or later (Andrews et al. 1986). Multiple Warp sandals may have first appeared prior to $6600 \mathrm{cal} \mathrm{BP}$, and sandals of this type were evidently made up to the historic period (Andrews et al. 1986). The small number that have been directly sampled or have unambiguous ${ }^{14} \mathrm{C}$ associations date to within the first half of the last millennium.

\section{REFERENCES}

Adovasio, JM. 1970. The origin, development and distribution of Western Archaic textiles and basketry. Tebiwa: Journal of the Idaho State University Museum 13(2): $1-40$.

Adovasio JM. 1986. Prehistoric Basketry. In: D'Azevedo WL, editor. Great Basin. Washington (DC): Smithsonian Institution. p 194-205. (Handbook of North American Indians; 11)

Aikens, CM. 1970. Hogup Cave. Salt Lake City: University of Utah. 286 p. (University of Utah anthropological papers; 93)

Andrews RL, Adovasio JM, Carlisle RC. 1986. Perishable industries from Dirty Shame Rockshelter, Malheur County, Oregon. Pittsburgh (PA): Department of Anthropology, University of Pittsburgh. 233 p. (Ethnology monographs; 9 . University of Oregon anthropological papers; 34 )

Arnold JR, Libby WF. 1951. Radiocarbon dates. Science 113(2927):111-20.

Bedwell SF, Cressman LS. 1971. Fort Rock report: prehistory and environment of the pluvial Fort Rock Lake area of south-central Oregon. In: Aikens CM, editor. Great Basin Anthropological Conference 1970: Selected Papers. Eugene: Department of Anthropology, University of Oregon. p 1-25. (University of Oregon anthropological papers; 1)

Berger R, Bendat M, Parker, A. 1998. America's oldest basketry. Radiocarbon 40(2):615-20.

Berger R, Fergusson GJ, Libby WF. 1965. UCLA radiocarbon dates IV. Radiocarbon 7:336-71

Berger R, Libby WF. 1966. UCLA radiocarbon dates V. Radiocarbon 8:467-97.

Connolly TJ. 1994. Prehistoric basketry from the Fort Rock Basin and vicinity. In: Aikens CM, Jenkins DL, editors. Archaeological researches in the northern Great Basin: Fort Rock archaeology since Cressman. Eugene: Department of Anthropology, University of Oregon. p 63-83. (University of Oregon anthropological papers; 50 )

Connolly TJ, Erlandson JM, Norris SE. 1995. Early Holocene basketry and cordage from Daisy Cave, San Miguel Island, California. American Antiquity 60(2): 309-18.

Connolly TJ, Fowler CS, Cannon WS. 1998. Radiocarbon evidence relating to northern Great Basin basketry chronology. Journal of California and Great Basin Anthropology 20(1):88-100.

Cowles J. 1959. Cougar Mountain Cave in south central Oregon. Rainier (WA): Daily News Press. 50 p.

Cressman LS. 1942. Archaeological researches in the 
northern Great Basin. Washington (DC): Carnegie Institution. 158 p. (Carnegie Institution of Washington publication 538)

Cressman LS. 1951 Western Prehistory in the light of carbon 14 dating. Southwestern Journal of Anthropology $7(3): 289-313$

Eiselt BS. 1997. Defining ethnicity in Warner Valley: an analysis of house and home [master's thesis]. Reno: University of Nevada, Reno. 216 p.

Fergusson GJ, Libby WF. 1962. UCLA radiocarbon dates. Radiocarbon 4:109-14.

Fowler CS, Cannon, WJ. 1992. Catlow twine and Warner Valley prehistory. Paper presented at: Great Basin Anthropological Conference; 1992 October 8-10; Boise, ID.
Fowler CS, Dawson LE. 1986. Ethnographic basketry. In: D'Azevedo WL, editor. Great Basin. Washington (DC): Smithsonian Institution. p 705-37. (Handbook of North American Indians; 11)

Hattori EM. 1982. The archaeology of Falcon Hill, Winnemucca Lake in Washoe County, Nevada. Carson City: Nevada State Museum. 208 p. (Nevada State Museum anthropological papers; 18)

Marchesini, R. 1994. Seven Mile Ridge Cave: a Late Archaic Site in Fort Rock Valley, Lake County, Oregon. In: Aikens, CM, Jenkins DL, editors. Archaeological researches in the northern Great Basin: Fort Rock archaeology since Cressman. Eugene: Department of Anthropology, University of Oregon. p. 171-212. (University of Oregon anthropological papers; 50)

\section{NOTE FROM AUTHORS OF ORIGINAL ARTICLE}

"We welcome the improvements presented by Connolly and Cannon filling in the archaeological/ archival record. Some of their information had not been available to us directly. Other data in the literature proved to be inaccurate in the end." - Rainer Berger, Millie Bendat, and Andrea Parker. 